\title{
Decomposition and nutrients released from forest and perennial crops associated with organic coffee
}

\author{
João Batista Silva Araujo1 (iD), Matheus Wandermurem da Silva1 (iD), Wallace Luís de Lima² (i), Ana Claudia Hertel Pereira ${ }^{3}$ (D), \\ Denise Coutinho Endringer ${ }^{3}$ (D) , Jacimar Luís de Souza ${ }^{1}$ (iD)
}

${ }^{1}$ Instituto Capixaba de Pesquisa Assistência Técnica e Extensão Rural/Incaper, Vitória, ES, Brasil

${ }^{2}$ Instituto Federal de Educação Ciência e Tecnologia do Espírito Santo/IFES, Alegre, ES, Brasil

${ }^{3}$ Universidade Vila Velha/UVV, Vila Velha, ES, Brasil

Contact authors: joaoaraujovni@gmail.com; matheus_wandermurem@hotmail.com; wallace@ifes.edu.br; anahertel@gmail.com; endringe@gmail.com; jacimar6@gmail.com Received in November 6, 2020 and approved in March 21, 2021

\begin{abstract}
Agroforestry consortia increase organic matter and nutrient cycling in agricultural systems. For this reason, the objective of this work was to study the release rate of nutrients and the decomposition of different organic residues, two times of the year, obtained from four cultures intercropped with conilon coffee, aiming to relate the released nutrients to the coffee needs. The decomposition of organic matter residues and the release of nutrients from Inga edulis, Musa spp, Gliricidia sepium, and Bactris gasipaes were evaluated in two different periods. I. edulis residues with a higher amount of polyphenols, and those of Musa spp, with a higher $\mathrm{C} / \mathrm{N}$ ratio, showed slow decomposition. The decomposition rates were lower in experiments started in March and higher in August. Inga and banana have high residual values of nutrients at 270 days in the decomposition started in March.
\end{abstract}

Key words: Agroforestry system; Organic coffee; SAF synchrony; Consortium; Low input.

\section{INTRODUCTION}

Agroforestry systems (SAFs) and consortia of perennial crops are important in the agroecological context, as they increase biodiversity and sustainability (Zapata Arango, 2019). Trees promote the increase of organic matter in SAFs and greater nutrient cycling, bringing nutrients from deeper levels to the soil surface, making them available for the crop of commercial interest (Isaac; Borden, 2019).

Among the species used in SAFs, legumes (Fabaceae), that fix nitrogen biologically (N-BNF), are important. The $\mathrm{N}$ of these fixing species can be transferred to the receiving plants by decomposition and mineralizing organic residues (Munroe; Isaac, 2014). The management of these shade trees is done, traditionally by coffee growers from Costa Rica, through pruning according to the coffee phenology. They prune at the end of the dry season to promote flowering and complete pruning before harvest to promote fruit ripening (Nygren et al., 2012).

There must be synchronization with the input of organic residues and the nutrients released to meet the coffee needs and their nutritional demands. For this reason, it is necessary to know the composition of residues and its decomposition rates (Duarte et al., 2013; Munroe; Isaac, 2014; Petit-Aldana et al., 2019). As the coffee demand for nutrients is highest during fruiting (DaMatta, 2007; Partelli et al., 2014), fertilization should occur between October and March (Partelli et al., 2014).

Decomposition can be evaluated with litterbags (PetitAldana et al., 2019) and covered litter (Ribas et al., 2010), aiming to facilitate soil fauna accessto organic residues. The results obtained generate mathematical models, including the single and double exponential (Petit-Aldana et al., 2019), generating decomposition and nutrient release curves.

Some species have a rapid decomposition, such as Gliricidia sepium (Kaba et al., 2019; Paula et al., 2015; PérezMarin; De Arruda Sarmento; Vendruscolo, 2018). Other species tend to be more recalcitrant and slow to decompose, such as Inga edulis (Leblanc; Nygren; Mcgraw, 2006), Inga semialata (Silva et al., 2008) and Inga subnuda (Duarte et al., 2013). So, if nutrient release is too fast, nutrients can be lost to leaching or volatilization, and if it is slow, they can be made available in insufficient quantities (Petit-Aldana et al., 2019).

The chemical composition of the residues, the community of decomposers and environmental factors such as soil, humidity and temperature influence the decomposition rate (Petit-Aldana et al., 2019). In the chemical composition, the $\mathrm{C} / \mathrm{N}$ ratio and $\mathrm{N}$, hemicellulose, cellulose, lignin and polyphenols content is important (Aita; Giacomini, 2003; Duarte et al., 2013; Handayanto; Cadish; Giller, 1994; Petit-Aldana et al., 2019; Silva et al., 2008). Higher levels of lignin and polyphenols provide recalcitrant behavior and higher levels of hemicellulose and cellulose labile behavior. Muchecheti and Madadze (2016), for example, observed rates of $\mathrm{N}$ release with $L$. leucocephala $>A$. angustissima $>C$. calothyrsus $>A$. karoo, being negatively correlated with lignin levels, soluble condensed tannins and lignin/N ratio. Duarte et al. (2013) observed Lignin/ $\mathrm{N}$ and $($ Lignin + polyphenol $) / \mathrm{N}$ ratios negatively correlated with $\mathrm{CO}_{2}$ flow, indicating less decomposition with higher lignin levels and polyphenols. 
Therefore, it's necessary to know the dynamics of the input of organic residues in the system, on which the productive response of the coffee will depend. The synchrony between coffee nutrition, the moment of application of organic residues and the decomposition rates can determine the best crop response. For this reason, the objective of this work was to study the decomposition and nutrients release from four different organic residues, at two times of the year, obtained from cultures intercropped with the conilon coffee tree, aiming to know the release of nutrients and relate to the coffee needs.

\section{MATERIAL AND METHODS}

This work was carried out at the Agroforestry System Observation Unit, implanted in January2013 at the Experimental Farm of Bananal do Norte (FEBN), with latitude $20^{\circ} 45^{\prime} 15.16^{\prime \prime} \mathrm{S}$, longitude $41^{\circ} 17^{\prime} 04.98^{\prime \prime} \mathrm{W}$ and altitude of 96 $\mathrm{m}$, in the municipality of Cachoeiro de Itapemirim, ES, Brazil. The local climate is tropical, with dry winter, of the Aw type in the Köppen-Geiger climate classification (Alvares et al., 2013). It has $18.0{ }^{\circ} \mathrm{C}$ of minimum temperature in the coldest month and $31^{\circ} \mathrm{C}$ in the warmest, average annual precipitation of 1,046 mm (Agrometeorologia, Incaper). During the study, precipitation was obtained using a pluviometer, already installed at the experimental farm (Figure 1).

The total area, $6,170 \mathrm{~m}^{2}$, was divided into five plots, with 15 sample points per plot, containing five coffee trees. One plot was planted with coffee in monoculture (CMON) and the other four in consortia with: inga (Inga edulis Mart) (CING); gliricidia (Gliricidia sepium Jacq. Steud) (CGLI); banana (Musa spp. cv. Japira) (CBAN) and peach palm (Bactris gasipaes Kunth) (CPP). The variety of Coffea canephora Emcaper 8151 (Robusta Tropical), with maturation in MayJune (Ferrão et al., 2017), was planted. The coffee tree was planted at $3.0 \times 1.0 \mathrm{~m}\left(3,333\right.$ plants $\left.\mathrm{ha}^{-1}\right)$; banana and peach palm were $3.0 \times 6.0 \mathrm{~m}$ (556 plants $\left.\mathrm{ha}^{-1}\right)$; for gliricidia and inga it was $6.0 \times 6.0 \mathrm{~m}\left(278\right.$ plants $\left.\mathrm{ha}^{-1}\right)$, replacing coffee trees in planting lines.

The fertilization was $80 \mathrm{~m}^{3} \mathrm{ha}^{-1}$ year-1 of organic compost, divided into November and February, providing, on average, in $\mathrm{kg} \mathrm{ha}^{-1}$ year $^{-1}: 147.1 \mathrm{~N} ; 29.4 \mathrm{P} ; 98.0 \mathrm{~K} ; 77.2 \mathrm{Ca}$ and $58.8 \mathrm{Mg}$. The compost was made with chicken manure, coffee husk, bovine manure, and Panicum maximum (Jacq.) grass. Chemical analyzes of soils were carried out in June 2017 (Table 1). Soil samples were collected with a manual post hole digger $\left(1.5 \mathrm{dm}^{3}\right)$, in the coffee canopy projection, $0.00-0.20 \mathrm{~m}$ deep, in 12 sampling points per plot, with three sub-samples per sample. The calculation for fertilization was made according to Prezotti (2020) for the productivity of 39.5 sc ha-1 (Ferrão et al., 2017).

The coffee tree was performed with four stems per plant. Peach palm was managed without pruning. The banana tree was conducted with three pseudostems per plant (Costa et al., 2006). Inga and gliricídia were pruned in March and August of each year, starting in March 2014, aiming at 35\% shade (Farfán; Baute, 2010). Gliricidia receiving drastic pruning (100\%) in August.

Biomass production was measured at six sample points with one plant per point. The total production of green matter at each point was weighed and samples

\section{Rainfall}

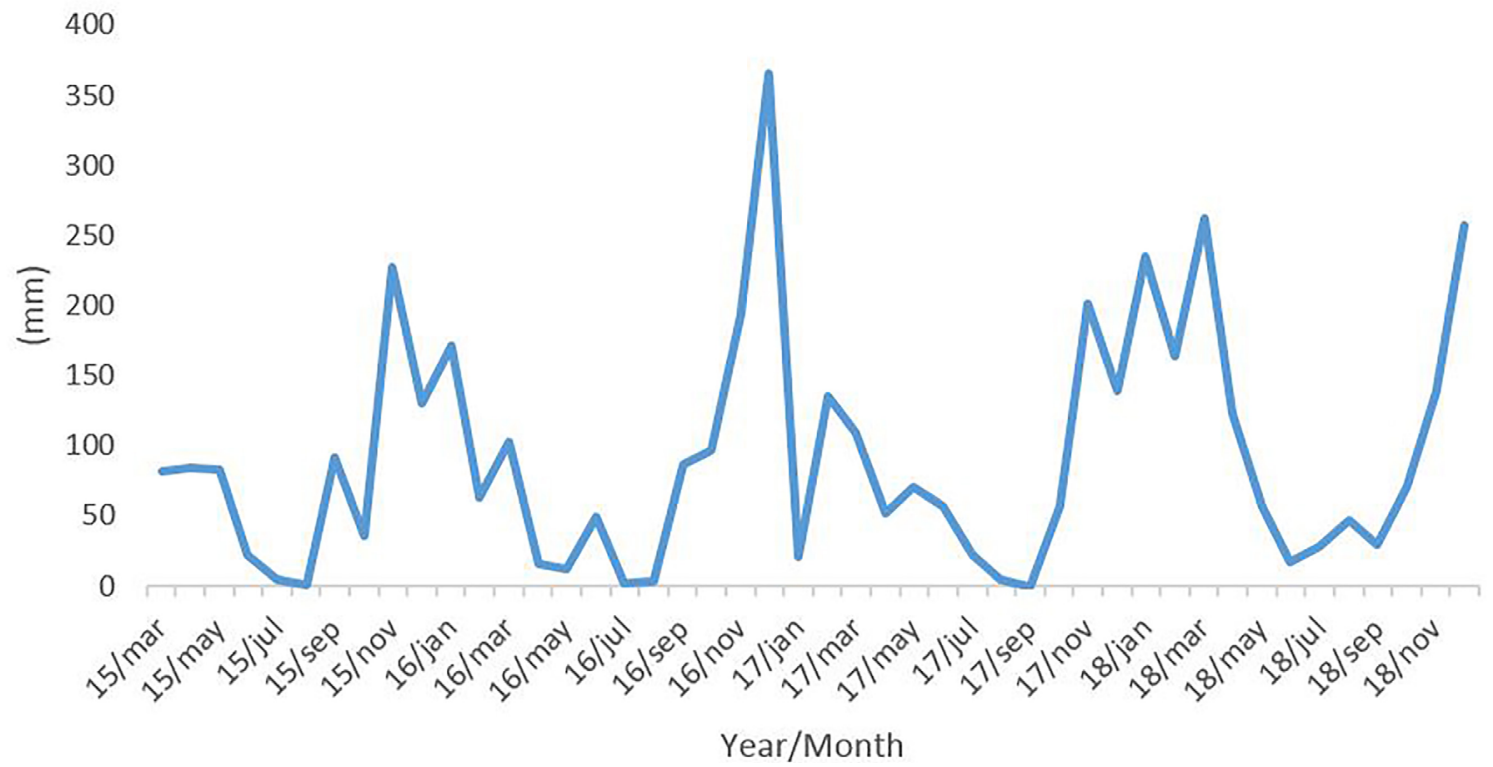

Figure 1: Monthly rainfall from March/2015 to December/2018, at FEBN, Cachoeiro de Itapemirim, ES. Source: Experimental Farm of Bananal do Norte, INCAPER. 
were collected. Weighing leaves and banana pseudostem were separate, collecting samples from one leaf and four pseudostem discs at points equidistant from the base to the top. The discs were $0.05 \mathrm{~m}$ high. The peach palm sample was from a medium leaf, collected after the palm heart was harvested. One branch per tree was collected to sample gliricidia and inga. At four equidistant points, between the tip and base of the branch, $0.10 \mathrm{~m}$ pieces were cut, including the leaves present in each part. The samples were dried at $65^{\circ} \mathrm{C}$ in a forced air circulation oven and then weighed, ground in a Willey milland analyzed to determine the nutrient content (Table 2). The biomass productivity was calculated by multiplying the average of the sample points by the number of plants per hectare (Table 3 ). The samples of gliricidia and inga were collected at the time of pruning and those of banana and peach palm were estimated in the harvests throughout 2017.

The neutral fiber analysis was performed according to the methodology described by Souza et al. (1999).
The equation obtains the fiber calculation in neutral detergent: NDF $(\%)=((\mathrm{CB}) \times 100) \mathrm{A}^{-1}$, where $\mathrm{A}$ is the mass of the sample, $B$ refers to the weight of the empty and dry crucible and $\mathrm{C}$ is the weight of the crucible with the residue at the end of the procedure. The analysis of acidic fiber (cellulose, lignin) was also performed as described by Souza et al. (1999). The same equation obtains the calculation of fiber in acid detergent as the neutral fiber.

The quantification of cellulose and lignin was adapted from the description by Gresser (Graça; Barlocher; Gressner, 2005). Briefly, to the crucible contents, $75 \%$ sulfuric acid was added and homogenized to break up the existing lumps, and the process was repeated three times. The calculation consists of \%lignin $=((\mathrm{DB})-(\mathrm{EB}))^{*} 100 \mathrm{~A}^{-1}$, where $A$ is the mass of the sample, $B$ refers to the weight of the empty and dry crucible and $\mathrm{C}$ is the weight of the crucible with the residue after adding the acid and $\mathrm{E}$ as the weight of the crucible with residue after incineration.

Table 1: Chemical attributes of the soil in monoculture conilon coffee (CMON) and intercropped with inga (CING), banana (CBAN), gliricidia (CGLI) and peach palm (CPP).

\begin{tabular}{|c|c|c|c|c|c|c|c|c|c|c|}
\hline Consortium & $\mathrm{pH}$ & $\mathrm{P}$ & $\mathrm{K}$ & $\mathrm{Ca}$ & $\mathrm{Mg}$ & $\mathrm{H}+\mathrm{Al}$ & SB and $t$ & $\mathrm{~T}$ & $\mathrm{~V}$ & SOM \\
\hline & & \multicolumn{2}{|c|}{$\left(\mathrm{g} \mathrm{kg}^{-1}\right)$} & \multicolumn{5}{|c|}{--- } & $(\%)$ & $\left(\mathrm{g} \mathrm{kg}^{-1}\right)$ \\
\hline CMON & 7.06 & 100.5 & 329.4 & 4.00 & 0.973 & 1.30 & 5.83 & 7.15 & 81.5 & 14.0 \\
\hline CING & 6.93 & 99.8 & 259.7 & 3.63 & 0.700 & 1.11 & 5.00 & 6.11 & 81.5 & 13.4 \\
\hline CBAN & 6.77 & 105.8 & 191.8 & 3.97 & 1.100 & 1.33 & 5.56 & 6.88 & 80.6 & 11.9 \\
\hline CGLI & 6.95 & 101.6 & 311.7 & 4.66 & 1.230 & 1.18 & 6.72 & 7.90 & 85.0 & 19.9 \\
\hline CPP & 6.89 & 78.9 & 347.5 & 4.13 & 0.818 & 1.32 & 5.84 & 7.16 & 81.4 & 18.5 \\
\hline
\end{tabular}

$\mathrm{pH}$, in $\mathrm{H}_{2} \mathrm{O}$; $\mathrm{P}$ e K: extractor Mehlich 1; $\mathrm{H}+\mathrm{AL}$ : potential acidity, extractor SMP; SB: sum of bases; (t): effective cation-exchange capacity; $\mathrm{T}$ : potential cation-exchange capacity; $\mathrm{BS}$, base saturation; SOM, soil organic matter (Oxidation $-\mathrm{Na}_{2} \mathrm{Cr}_{2} \mathrm{O}_{7}+\mathrm{H}_{2} \mathrm{SO} \mathrm{O}_{4} 10 \mathrm{~N}$ ).

Table 2: Nutrient content in residues of species intercropped with conilon coffee. Cachoeiro de Itapemirim, ES.

\begin{tabular}{|c|c|c|c|c|c|c|c|}
\hline Date & Species & $\mathrm{C} / \mathrm{N}$ & $\mathrm{N}$ & $\mathrm{P}$ & $\mathrm{K}$ & $\mathrm{Ca}$ & $\mathrm{Mg}$ \\
\hline & & & \multicolumn{5}{|c|}{$\left(\mathrm{g} \mathrm{kg}^{-1}\right)$} \\
\hline \multirow[t]{4}{*}{ 27/Mar/2015 } & Inga & 35.2 & 15.17 & 1.44 & 9.07 & 7.21 & 1.23 \\
\hline & Gliricidia & 18.2 & 27.83 & 1.28 & 8.96 & 11.40 & 3.44 \\
\hline & Banana & 68.8 & 8.17 & 1.56 & 8.13 & 9.39 & 5.44 \\
\hline & Peach palm & 33.4 & 18.73 & 2.25 & 10.32 & 5.10 & 2.66 \\
\hline \multirow[t]{4}{*}{ 03/Aug/2016 } & Inga & 26.5 & 22.68 & 1.20 & 5.63 & 10.79 & 1.06 \\
\hline & Gliricidia & 25.7 & 22.03 & 1.12 & 7.09 & 10.57 & 2.73 \\
\hline & Banana & 48.2 & 11.62 & 0.91 & 12.29 & 12.29 & 2.75 \\
\hline & Peach palm & 33.1 & 13.79 & 2.21 & 12.71 & 6.43 & 1.77 \\
\hline \multirow[t]{4}{*}{ 29/Mar/2017 } & Inga & 40.6 & 14.21 & 0.92 & 8.34 & 5.96 & 0.40 \\
\hline & Gliricidia & 39.9 & 13.84 & 0.93 & 11.46 & 6.57 & 2.34 \\
\hline & Banana & 91.1 & 6.09 & 0.70 & 22.29 & 6.57 & 2.27 \\
\hline & Peach palm & 26.9 & 20.53 & 2.06 & 14.59 & 2.75 & 1.88 \\
\hline
\end{tabular}

$\mathrm{N}$ : sulfuric digestion with titrometric determination; $\mathrm{P}, \mathrm{K}, \mathrm{Ca}$ and $\mathrm{Mg}$ : Nitro-perchloric digestion. C: muffle combustion at $550^{\circ} \mathrm{C}$. 
Table 3: Green matter (GM), dry matter (DM) and total nutrients of compost (COMP) and inga (ING), banana (BAN), gliricídia (GLI) and peach palm (PP). Cachoeiro de Itapemirim, ES.

\begin{tabular}{|c|c|c|c|c|c|c|c|}
\hline Source & GM & $\mathrm{DM}$ & $\mathrm{N}$ & $\mathrm{P}$ & $\mathrm{K}$ & $\mathrm{Ca}$ & $\mathrm{Mg}$ \\
\hline & $\left(\mathrm{t} \mathrm{ha}^{-1}\right)$ & $\left(\mathrm{t} \mathrm{ha}^{-1}\right)$ & & & $\left(\mathrm{kg} \mathrm{ha}^{-1}\right)$ & & \\
\hline Compost & 20.90 & 12.26 & 147.12 & 29.40 & 98.00 & 77.20 & 58.80 \\
\hline ING (a) & 13.50 & 5.34 & 121.11 & 6.41 & 30.06 & 57.62 & 5.66 \\
\hline ING (b) & 6.16 & 3.17 & 45.01 & 2.85 & 26.31 & 19.02 & 1.27 \\
\hline GLI (a) & 15.70 & 7.34 & 161.70 & 8.22 & 52.04 & 77.58 & 20.04 \\
\hline GLI (b) & 13.77 & 4,70 & 64.86 & 4.23 & 54.05 & 31.02 & 10.81 \\
\hline BAN & 9.72 & 1.46 & 12.92 & 1.17 & 25.22 & 13.77 & 3.68 \\
\hline $\mathrm{PP}$ & 3.26 & 0.96 & 13.20 & 2.11 & 12.16 & 6.15 & 1.69 \\
\hline \multicolumn{8}{|l|}{ Amount } \\
\hline $\mathrm{COMP}+\mathrm{ING}$ & 40.57 & 20.77 & 313.24 & 38.66 & 154.37 & 153.84 & 65.73 \\
\hline $\mathrm{COMP}+\mathrm{GLI}$ & 50.38 & 24.30 & 373.68 & 41.85 & 204.09 & 185.80 & 89.65 \\
\hline $\mathrm{COMP}+\mathrm{BAN}$ & 30.63 & 13.72 & 160.04 & 30.57 & 123.22 & 90.97 & 62.48 \\
\hline $\mathrm{COMP}+\mathrm{PP}$ & 24.17 & 13.22 & 160.32 & 31.51 & 110.16 & 83.35 & 60.49 \\
\hline
\end{tabular}

Compost applied in the agricultural year 2016/17. Banana and peach palm residues measured throughout 2017, and inga and gliricidia at the time of pruning on 08/Mar/2016 (a) and 29/Aug/2017 (b).

The determination of polyphenols was performed according to Krepsky et al. (2012), with adaptations. The analyzes were performed in a microplate with a reading at $715 \mathrm{~nm}$ of the reaction product between the solution of the plant material with the Folin-Ciocalteau reagent and sodium carbonate. As a standard, gallic acid was used, the results being expressed in gallic acid equivalent $100 \mathrm{~g}^{-1}$.

The biomass loss of dry matter and nutrients of inga (DM-ING), banana (DM-BAN), gliricidia (DM-GLI) and peach palm (DM-PP) were evaluated. Fresh matter samples of $0.20 \mathrm{~kg}$ of each species were placed on the ground (covered litter), under the coffee canopy, covered with 0.30 x $0.30 \mathrm{~m}$ screens and 0.004 x $0.004 \mathrm{~m}$ mesh (Ribas et al., 2014). Three decomposition evaluations were made with the first one started on 27/Mar/2015, with collection at 0,7 , $15,25,40,60,90,120$ and 150 days, and three replications arranged in randomized block design. In the second and third evaluations, started on 03/Aug/2016 and 29/Mar/2017, the period for DM-ING and DM-BAN was extended with collections at $0,7,30,60,90,120,150,190,230$ and 270 days, because the half-life ( $\mathrm{t} 1 / 2)$ was not reached in the first evaluation. The remaining biomass samples were cleaned to remove the adhered soil, dried at $65{ }^{\circ} \mathrm{C}$ in a forced air circulation oven, crushed in a Willey mill and analyzed to determine the levels of $\mathrm{N}, \mathrm{P}, \mathrm{K}, \mathrm{Ca}$ and $\mathrm{Mg}$.

Decomposition rates of dry matter and mineralization of nutrients from green manureswere determined by non-linear regression models, described by Wieder and Lang (1982) as cited by Aita and Giacomini (2003). The asymptotic model has the following mathematical equation: $\mathrm{DMR}$ or $\mathrm{NR}=\mathrm{A}$ $\mathrm{e}^{-\mathrm{kat}}$, where: DMR and NR correspond to the percentage of dry matter and nutrient remaining at time $t$; $t$ is the sampling time from 0 to 150 or 270 days; $k a$ is the constant rate of dry matter decomposition and nutrient mineralization. DMR and NR were calculated relative to DM and nutrients at time zero for each sampling time. From the decomposition constants of the DMR or NR, it was calculated the half-life time $(\mathrm{t} 1 / 2)$ required for $50 \%$ to be mineralized to the soil, using the equation $(\mathrm{t} 1 / 2)$ $=\ln 0.5 \mathrm{k}^{-1}$, according to Paul and Clark (1996).

The organic matter composition data were submitted to variance analysis and the Tukey test's averages at 5\% probability. The decomposition variables were analyzed using regression analysis, and the parameters of the mathematical equations were tested for significance level using the t test, using the Genes program (Cruz, 2013).

\section{RESULTS}

The chemical compositions of dry matter residues are shown in Table 4. In the second collection (03/August/2016) the DM-ING presented higher levels of cellulose $(22.36 \%)$, LG (21.55\%) and PPs (3.824\%), as well as a higher LG/N (1.033) and $(\mathrm{LG}+\mathrm{PPs}) / \mathrm{N}(1.210)$ ratio than the other residues. The DMBAN presented higher levels of hemicellulose (19.99\%) and C/N ratio (48.2). The DM-GLI presented lower levels of hemicellulose (4.62\%), intermediates of cellulose (12.38\%) and lignin (13.56\%). The DM-PP presented higher levels of hemicellulose (12.38\%) and lower levels of cellulose (9.09\%) and LG (7.72\%).

In the third collection (29/March/2017), the DM-PP showed higher levels of hemicellulose $(21.10 \%)$ concerning to the other sources $(6.31 \%$ to $10.60 \%)$ (Table 4$)$. The DMBAN presented higher $\mathrm{C} / \mathrm{N}$ ratio $(91.0)$ and lower levels of PPs $(0.425 \%)$. DM-ING showed higher polyphenols levels $(2.134 \%)$ compared to other sources $(0.425 \%$ to $1.081 \%)$. 
Table 4: Chemical composition of inga, gliricidia, banana and peach palm collected on 03/August/2016 and 29/March/2017.

\begin{tabular}{|c|c|c|c|c|c|c|c|}
\hline Plant & $\mathrm{C} / \mathrm{N}$ & Hemic. & Cellulose & LG & PPs & LG/N & $(\mathrm{LG}+\mathrm{PP}) / \mathrm{N}$ \\
\hline & & $(\%)$ & $(\%)$ & $(\%)$ & $(\%)$ & & \\
\hline Inga & $26.5 \mathrm{~b}$ & $4.06 \mathrm{c}$ & $22.36 \mathrm{a}$ & $21.55 \mathrm{a}$ & $3.697 \mathrm{a}$ & $1.034 \mathrm{a}$ & $1.211 \mathrm{a}$ \\
\hline Banana & $48.2 \mathrm{a}$ & $19.99 \mathrm{a}$ & $7.28 \mathrm{c}$ & $7.16 \mathrm{c}$ & $0.897 \mathrm{~b}$ & $0.621 \mathrm{~b}$ & $0.699 \mathrm{~b}$ \\
\hline Gliricidia & $25.7 \mathrm{~b}$ & $6.05 \mathrm{bc}$ & $12.38 \mathrm{~b}$ & $13.56 \mathrm{~b}$ & $0.847 \mathrm{~b}$ & $0.640 \mathrm{~b}$ & $0.682 \mathrm{~b}$ \\
\hline Peach palm & $33.1 \mathrm{~b}$ & $12.38 \mathrm{ab}$ & $9.09 \mathrm{bc}$ & $7.72 \mathrm{c}$ & $0.707 \mathrm{~b}$ & $0.465 \mathrm{~b}$ & $0.507 \mathrm{~b}$ \\
\hline Inga & $40.6 \mathrm{~b}$ & $6.31 \mathrm{~b}$ & 23.60 & 23.57 & $2.134 \mathrm{a}$ & 1.686 & 1.825 \\
\hline Banana & $91.0 \mathrm{a}$ & $10.60 \mathrm{~b}$ & 8.48 & 8.74 & $0.425 \mathrm{~b}$ & 1.420 & 1.491 \\
\hline Gliricidia & $39.9 \mathrm{~b}$ & $8.78 \mathrm{~b}$ & 26.82 & 26.53 & $0.432 \mathrm{~b}$ & 1.901 & 1.939 \\
\hline Peach palm & $26.9 \mathrm{~b}$ & $21.10 \mathrm{a}$ & 10.64 & 11.86 & $1.081 \mathrm{ab}$ & 0.579 & 0.633 \\
\hline
\end{tabular}

Means followed by the different letter in the columns differ by Tukey's test $(p \leq 0.05)$. Hemic.: Hemicellulose; PP: poliyphenols; LG/N: lignina/ nitrogen (LG+PP)/N: (lignin+polyphenol)/nitrogen.

The first evaluation, between 27/Mar to 23/Aug/2015, was in the dry season (Table 1) of autumn-winter, without adjusting the equations of DM-ING and DM-BAN (Table 5), indicating accumulation on the soil. DM-GLI and DM-PP had $\mathrm{t} 1 / 2$, respectively, at 109.1 and 82.9 days. In the second evaluation, started on 03/Aug/2016, the t1/2 of the DM was between 87.9 days (DM-PP) and 207.1 days (DM-ING) (Table 6 ). In the third assessment, started in $29 / \mathrm{Mar} / 2017$, t1/2 was reached only at DM-PP at 108.0 days (Table 7).

In the first evaluation, the $t 1 / 2$ of the nutrients from DM-GLI was between 39.5 days $(\mathrm{K})$ and 63.5 days $(\mathrm{N})$, and from DM-PP between 40.3 days $(\mathrm{K})$ and 79.1 days $(\mathrm{N})$ (Table 5). The $t 1 / 2$ of the DM-ING was reached with $\mathrm{K}$ at 101.9 days, with immobilization of $\mathrm{Ca}(119.5 \%)$ and $\mathrm{Mg}$ (115.8\%), without adjustment for $\mathrm{N}$ and $\mathrm{P}$. With DM-BAN t1/2 was not achieved with all nutrients. In the second evaluation, which started on $03 / \mathrm{Aug} / 2016$, the $t 1 / 2$ of the nutrients ranged from 62.3 days $(\mathrm{K})$ to 135.2 days $(\mathrm{Ca})$ in the DM-BAN; 60.5 days $(\mathrm{K})$ to 90.0 days $(\mathrm{Ca})$ on DM-GLI; 47.5 days $(\mathrm{K})$ to $107.9(\mathrm{Ca})$ of DM-PP; and 137.8 days $(\mathrm{P})$ to 263.2 days $(\mathrm{Mg})$ on DMING, and not reached with Ca in DM-ING (Table 6).

In the evaluation started on 29/Mar/2017 the nutrients t1/2 was reached between 55.1 days $(\mathrm{K})$ and 136.3 days $(\mathrm{Ca})$ in the DM-PP; between 46.8 days $(\mathrm{K})$ and 135.1 days $(\mathrm{S})$ on DMGLI, without adjustment in the Ca equation (Table 7). With DM-BAN, only $\mathrm{t} 1 / 2$ of $\mathrm{K}$ was reached at 92.3 days and with DM-ING the $t 1 / 2$ of the studied nutrients was not reached.

\section{DISCUSSION}

The decomposition rate shows a negative correlation with the levels of lignin and polyphenols, the $\mathrm{C} / \mathrm{N}, \mathrm{LG} / \mathrm{N}$ and (LG+PPs)/ $\mathrm{N}$ ratios and positive with hemicellulose and cellulose levels (Petit-Aldana et al., 2019). Silva et al. (2008) observed a higher decomposition rate of $G$. sepium than $I$. semialata, with respective values of 31.9 and $72.7 \mathrm{~g} \mathrm{~kg}^{-1}$ of
PPs, 74.5 and $237.4 \mathrm{~g} \mathrm{~kg}^{-1}$ of LG, 0,83 e 3,08 de PPs/N, 1,93 e 10,06 de LG/N, 2,76 e 13,14 de (LG+PPs)/N. Also, Duarte et al. (2013) observed a low decomposition rate of I. subnuda with a higher ratio $(\mathrm{LG}+\mathrm{PPs}) / \mathrm{N}$ (10.1). For this reason, the higher levels of LG (21.55\%) and PPs (3.697\%) in 2016 and PPs 2,134) in the 2017 collection, with higher LG/N $(1,034)$ and $(\mathrm{LG}+\mathrm{PPs}) / \mathrm{N}(1,211)$ ratios, give $\mathrm{DM}-\mathrm{ING}$ a recalcitrant character.

Despite not containing high levels of LG and PPs, the banana residues showed low decomposition rate. However, higher $\mathrm{C} / \mathrm{N}$ ratios lead to a lower decomposition rate, and ratios below 40 are recommended for composting (Acosta et al., 2014) so that there is no immobilization of nutrients (Giacomini et al., 2015). For this reason, the high $\mathrm{C} / \mathrm{N}$ ratio of the DM-BAN, between 48.0 and 91.0, induces greater recalcitrance and immobilization of nutrients.

The DM-GLI presents rapid decomposition, with $\mathrm{t} 1 / 2$ of the oxidizable carbon of leaves at 30 days (Nyamai, 1992), loss of $69 \%$ of the dry matter after 70 days (Zaharah; Bah, 1999), t1/2 of the dry matter after 21 days (Silva et al., 2008) and $t 1 / 2$ of 21 days in the dry season and 13 days in the rainy season (Paula et al., 2015). The observed decomposition was slower with $\mathrm{t} 1 / 2$ of the DM-GLI at 109.1 and 132.3 days in the first and second evaluations and not reached in the third. This result is certainly due to the use of whole branches and not just leaves. The evaluation of whole branches is justified because the ratio of branches/leaves of gliricidia is $7 / 1$, with $30 \%$ of $\mathrm{N}$ in the leaves (Kaba et al., 2019) and, therefore, evaluating only leaves would underestimate $70 \%$ of $\mathrm{N}$ contained in $87.5 \%$ of the biomass.

Unlike gliricidia, species of the genus Inga tend to slowly decompose the leaves with $\mathrm{t} 1 / 2$ of 269 days of $I$. semialata, $69 \%$ of dry matter remaining after 150 days for $I$. subnuda (Duarte et al., 2013) and $67 \%$ of dry matter remaining of $I$. edulis after 20 weeks (Leblanc et al., 2006). In this study, the decomposition rates were lower with the $t 1 / 2$ of the DM- 
ING reached in 207.1 days only in the second evaluation. This resulted from the use of whole branches and not just leaves, giving a more recalcitrant character. As the pruning residue is made up of whole branches, the leaf decomposition rates estimate will tend to overestimate the decomposition and the nutrients released.

In the three evaluations analyzed, the DM-PP showed remnants of $24.1 \%, 23.8 \%$ and $35.2 \%$ at 150 days. Pereira et al. (2015) observed that faster decomposition with $99.7 \%$ of the DM-PP decomposed at 112 days, due to the material crushed and buried at a depth of $10 \mathrm{~cm}$, facilitating the decomposition. This higher rate of decomposition of peach palm is due to the composition of the residue with a higher hemicellulose content and a tendency to lower levels of cellulose, lignin and polyphenols in comparison with the ingá residue. Hemicellulose gives it a labile character and, mainly, lignin and polyphenols recalcitrant character (Petit-Aldana et al., 2019).

Unlike peach palm, the banana tree had a slow decomposition. Brito et al. (2017) observed a slow decomposition of Japira banana litter, with a $11 / 2$ of 236 days in an irrigated system, corroborating the results of the first and third evaluations, with strong recalcitrance and without adjustment of the equations. However, it was slower than in the second evaluation of the present study with $\mathrm{t} 1 / 2$ at 108 days, a fact explained by the lower $\mathrm{C} / \mathrm{N}$ ratio (48/1). In addition, the higher speed released of nutrients from the second evaluation, for all plants studied, coincides with the rainiest period and more humid that favors decomposition (Bona et al., 2006; Paula et al., 2015).

Table 5: Parameters of the equation $\mathrm{X}=\mathrm{X} 0 \mathrm{e}^{-\mathrm{kt}}$ adjusted to the values of dry matter (DM), N, P, K, Ca, Mg and S, half-life times, and dry matter and nutrients remaining at 150 days, of inga, banana, gliricídia and peach palm, between 27/Mar and 23/Aug/2015.

\begin{tabular}{|c|c|c|c|c|c|c|}
\hline Variable & Source & $\mathrm{X}_{0}$ & $\mathrm{~K}$ & $t_{(1 / 2)}$ & $\mathrm{X}_{150}$ & $r^{2}$ \\
\hline & & (day) & & & (day) & \\
\hline & & $(\%)$ & & (day) & $(\%)$ & \\
\hline \multirow[t]{4}{*}{$\mathrm{DM}$} & Inga & 90.74180 & $0.000114^{\mathrm{ns}}$ & ---- & --- & 0.9 \\
\hline & Banana & 99.77271 & $-0.000343^{\mathrm{ns}}$ & ---- & --- & 3.4 \\
\hline & Gliricídia & 88.34810 & $-0.006351 * *$ & 109.1 & 34.1 & 87.7 \\
\hline & Peach palm & 83.47488 & $-0.008360 * *$ & 82.9 & 24.1 & 89.9 \\
\hline \multirow[t]{4}{*}{$\mathrm{N}$} & Inga & 77.88238 & $-0.000553^{\mathrm{ns}}$ & ---- & --- & 2.7 \\
\hline & Banana & 78.44304 & $-0.001844^{\mathrm{ns}}$ & ---- & --- & 9.5 \\
\hline & Gliricídia & 70.48606 & $-0.010912 * *$ & 63.5 & 13.7 & 76.1 \\
\hline & Peach palm & 76.65099 & $-0.008758 * *$ & 79.1 & 20.6 & 86.9 \\
\hline \multirow[t]{4}{*}{$\mathrm{P}$} & Inga & 85.46083 & $-0.002484^{\mathrm{ns}}$ & ---- & --- & 39.7 \\
\hline & Banana & 83.53100 & $-0.002692^{\mathrm{ns}}$ & ---- & --- & 37.0 \\
\hline & Gliricídia & 96.90686 & $-0.012716 * *$ & 54.5 & 14.4 & 91.5 \\
\hline & Peach palm & 88.32134 & $-0.009282 * *$ & 74.7 & 21.9 & 93.3 \\
\hline \multirow[t]{4}{*}{ K } & Inga & 87.79091 & $-0.006804 * *$ & 101.9 & 31.6 & 81.2 \\
\hline & Banana & 87.58088 & $-0.003340^{\mathrm{ns}}$ & ---- & --- & 31.4 \\
\hline & Gliricídia & 96.15311 & $-0.017545 * *$ & 39.5 & 6.9 & 93.6 \\
\hline & Peach palm & 95.86467 & $-0.017206^{* *}$ & 40.3 & 7.3 & 88.1 \\
\hline \multirow[t]{4}{*}{$\mathrm{Ca}$} & Inga & 79.05066 & $0.002755^{*}$ & ---- & 119.5 & 56.1 \\
\hline & Banana & 10.99765 & $0.000680^{\mathrm{ns}}$ & ---- & --- & 12.5 \\
\hline & Gliricídia & 10.06754 & $-0.010938 * *$ & 63.4 & 20.8 & 81.7 \\
\hline & Peach palm & 85.35707 & $-0.004991 * *$ & 138.9 & 40.4 & 75.2 \\
\hline \multirow[t]{4}{*}{$\mathrm{Mg}$} & Inga & 90.62417 & $0.001637 * *$ & ---- & 115.8 & 65.5 \\
\hline & Banana & 86.04277 & $-0.003494 *$ & ---- & 50.9 & 46.2 \\
\hline & Gliricídia & 10.77418 & $-0.013017 * *$ & 53.2 & 15.3 & 82.6 \\
\hline & Peach palm & 93.44513 & $-0.009625 * *$ & 72.0 & 22.1 & 86.3 \\
\hline
\end{tabular}

${ }^{*}$ and **: Significant, respectively, at $5 \%$ and $1 \%$. 
Table 6: Parameters of the equation $\mathrm{X}=\mathrm{X} 0 \mathrm{e}^{-\mathrm{kt}}$, adjusted to the values of dry matter (DM), N, P, K, Ca, Mg and S, half-life time (t1/2), DM and remaining nutrients at 150 and 270 days, from inga, banana, gliricídia and peach palm, between 03/Aug/2016 and 28/Apr2017.

\begin{tabular}{|c|c|c|c|c|c|c|c|}
\hline Variable & Species & $X_{0}$ & K & $t_{(1 / 2)}$ & $\mathrm{X}_{150}$ & $\mathrm{X}_{270}$ & $r^{2}$ \\
\hline & & (day) & & & (day) & (day) & \\
\hline & & $(\%)$ & & (day) & $(\%)$ & $(\%)$ & \\
\hline \multirow[t]{4}{*}{$\mathrm{DM}$} & Inga & 101.04152 & $-0.003347 * *$ & 207.1 & 61.2 & 40.9 & 92.0 \\
\hline & Banana & 102.66986 & $-0.006383 * *$ & 108.6 & 39.4 & 18.3 & 93.9 \\
\hline & Gliricidia & 94.09034 & $-0.005239 * *$ & 132.3 & 42.9 & -- & 94.4 \\
\hline & Peach palm & 101.51833 & $-0.007886^{* *}$ & 87.9 & 31.1 & -- & 98.6 \\
\hline \multirow[t]{4}{*}{$\mathrm{N}$} & Inga & 92.22597 & $-0.004154 * *$ & 166.9 & 49.5 & 30.0 & 94.9 \\
\hline & Banana & 104.64953 & $-0.005959 * *$ & 116.3 & 42.8 & 20.9 & 80.3 \\
\hline & Gliricidia & 81.13838 & $-0.010566^{* *}$ & 65.6 & 16.8 & -- & 94.4 \\
\hline & Peach palm & 94.82329 & $-0.009209 * *$ & 75.3 & 23.8 & -- & 97.9 \\
\hline \multirow[t]{4}{*}{$\mathrm{P}$} & Inga & 108.47588 & $-0.005029 * *$ & 137.8 & 51.0 & 27.9 & 89.1 \\
\hline & Banana & 98.30920 & $-0.006337 * *$ & 109.4 & 38.0 & 17.8 & 93.5 \\
\hline & Gliricidia & 78.66487 & $-0.009333 * *$ & 74.3 & 19.4 & -- & 93.7 \\
\hline & Peach palm & 116.66510 & $-0.011810^{* *}$ & 58.7 & 19.8 & -- & 96.9 \\
\hline \multirow[t]{4}{*}{ K } & Inga & 132.80198 & $-0.004905 * *$ & 141.3 & 63.6 & 35.3 & 85.7 \\
\hline & Banana & 97.01592 & $-0.011131^{* *}$ & 62.3 & 18.3 & 4.8 & 74.1 \\
\hline & Gliricidia & 121.24075 & $-0.011457 * *$ & 60.5 & 21.7 & -- & 96.3 \\
\hline & Peach palm & 169.62197 & $-0.014599 * *$ & 47.5 & 19.0 & -- & 86.6 \\
\hline \multirow[t]{4}{*}{$\mathrm{Ca}$} & Inga & 105.08267 & $-0.002203 * *$ & --- & 75.5 & 58.0 & 79.5 \\
\hline & Banana & 106.18003 & $-0.005126^{* *}$ & 135.2 & 49.2 & 26.6 & 76.4 \\
\hline & Gliricidia & 108.75110 & $-0.007698 * *$ & 90.0 & 34.3 & -- & 88.2 \\
\hline & Peach palm & 105.56862 & $-0.006422 * *$ & 107.9 & 40.3 & -- & 94.2 \\
\hline \multirow[t]{4}{*}{$\mathrm{Mg}$} & Inga & 80.75891 & $-0.002634 * *$ & 26.2 & 54.4 & 39.7 & 74.8 \\
\hline & Banana & 127.35682 & $-0.007217 * *$ & 96.0 & 43.1 & 18.1 & 90.4 \\
\hline & Gliricidia & 117.65303 & $-0.010263 * *$ & 67.5 & 25.2 & -- & 94.4 \\
\hline & Peach palm & 94.03476 & $-0.009205 * *$ & 75.3 & 23.6 & -- & 93.6 \\
\hline
\end{tabular}

${ }^{*}$ and ${ }^{* *}$ : Significant, respectively, at $5 \%$ and $1 \%$.

As the decomposition rate is different among the residues, they can meet the needs of the coffee at different times. Tree pruning occurs before flowering and before coffee harvest (Nygren et al., 2012), meeting the need to reduce shade in crucial phenological stages, favoring the formation of flowers and fruit maturation. The flowering of Conilon coffee takes place from July to November (DaMatta, 2007), with more than $90 \%$ of flowers opened in early September, in nonirrigated condition (Marsetti et al., 2013).

The stages of fruit development coffee, in weeks after flowering, are: pinhead (up to 6th or 10th); rapid swelling (from 6th and 17th); suspended and slow growth (two weeks); endosperm filling (between 17th to 28th); and ripe (between the 24th to the 34th) (DaMatta, 2007). The highest fruit accumulation rates are found between the rapid swelling stage and endosperm filling, with $100 \%, 96 \%, 52 \%$ and $38 \%$ of the total $\mathrm{N}$ accumulated in early, intermediate, late and very late varieties, respectively, on 12March (Partelli et al., 2014). In this case, for intermediate varieties, fertilization must take place before March 12 for fruit formation, being a parameter to evaluate the efficiency of nutrients released by organic residues.

Gliricidia results demonstrate fast nutrients release, with $79 \%$ of $\mathrm{P}, 99 \%$ of $\mathrm{K}, 91 \%$ of $\mathrm{Ca}$ and $82 \%$ of Mg released of leaves after 70 days of incubation (Zaharah; Bah, 1999) and 74\%, 87\% and $94 \%$ of N, P and $\mathrm{K}$ released from fragmented thin branches after 15 days of decomposition, respectively (Pérez-Marin et al., 2018). In the present study, the release rates were slower, possibly because whole branches were used.The $t 1 / 2$ occurred between 39.5 days $(\mathrm{K})$ and 63.5 days $(\mathrm{N})$ in the first evaluation; between 60.5 days $(\mathrm{K})$ to 90.0 days $(\mathrm{Ca})$ in the first evaluation; between 46.8 days $(\mathrm{K})$ and 135.1 days $(\mathrm{S})$ in DM-GLI, without adjustment in the $\mathrm{Ca}$ equation in the third evaluation. 
Table 7: Parameters of the equation $\mathrm{X}=\mathrm{X} 0 \mathrm{e}^{-\mathrm{kt}}$, adjusted to the values of dry matter (DM), N, P, K, Ca, Mg and S, half-life time (t1/2), DM and remaining nutrients at 150 and 270 days, from inga, banana, gliricidia and peach palm, between 29/Mar and 23/ Dec/2017.

\begin{tabular}{|c|c|c|c|c|c|c|c|}
\hline Variable & Species & $\mathrm{X}_{0}$ & $\mathrm{~K}$ & $t_{(1 / 2)}$ & $\mathrm{X}_{150}$ & $\mathrm{X}_{270}$ & $\mathrm{r}^{2}$ \\
\hline & & (day) & & & (day) & (day) & \\
\hline & & $(\%)$ & & (day) & $(\%)$ & $(\%)$ & \\
\hline \multirow[t]{4}{*}{$\mathrm{DM}$} & Inga & 93.96059 & $-0.000843^{\text {ns }}$ & --- & --- & --- & 32.3 \\
\hline & Bananeira & 104.80921 & $-0.000060^{\mathrm{ns}}$ & --- & --- & --- & 00,1 \\
\hline & Gliricidia & 96.71204 & $-0.003370^{* *}$ & --- & 58.3 & & 79.8 \\
\hline & Peach palm & 92.13614 & $-0.006419^{* *}$ & 108.0 & 35.2 & & 81.7 \\
\hline \multirow[t]{4}{*}{$\mathrm{N}$} & Inga & 100.25174 & $-0.001348^{*}$ & -- & 81.9 & 69.7 & 60.7 \\
\hline & Bananeira & 137.76177 & $0.002242^{\mathrm{ns}}$ & -- & --- & --- & 34.7 \\
\hline & Gliricidia & 94.35499 & $-0.005395^{* *}$ & 128.5 & 42.0 & & 75.0 \\
\hline & Peach palm & 86.81135 & $-0.009289^{* *}$ & 74.6 & 21.5 & & 79.6 \\
\hline \multirow[t]{4}{*}{$\mathrm{P}$} & Inga & 101.83421 & $-0.001255^{*}$ & --- & 84.4 & 72.6 & 52.0 \\
\hline & Bananeira & 118.30578 & $0.002530^{\mathrm{ns}}$ & --- & --- & --- & 33.0 \\
\hline & Gliricidia & 112.82335 & $-0.005624 * *$ & 123.2 & 48.5 & & 84.1 \\
\hline & Peach palm & 100.48715 & $0.006397^{* *}$ & 110.1 & 39.1 & & 85.4 \\
\hline \multirow[t]{4}{*}{$\mathrm{K}$} & Inga & 98.08809 & $-0.001848 * *$ & --- & 74.3 & 59.6 & 80.9 \\
\hline & Bananeira & 84.44094 & $-0.007512^{* *}$ & 92.3 & 27.4 & 11.1 & 87.7 \\
\hline & Gliricidia & 117.28988 & $-0.014818^{* *}$ & 46.8 & 12.7 & & 90.2 \\
\hline & Peach palm & 102.84535 & $-0.012579 * *$ & 55.1 & 15.6 & & 83.0 \\
\hline \multirow[t]{4}{*}{$\mathrm{Ca}$} & Inga & 111.73582 & $-0.000038^{\mathrm{ns}}$ & --- & --- & --- & 0.1 \\
\hline & Bananeira & 135.64112 & $0.002476^{*}$ & --- & 196.6 & 264.7 & 45.7 \\
\hline & Gliricidia & 123.01469 & $-0.003427^{\mathrm{ns}}$ & --- & --- & & 28.2 \\
\hline & Peach palm & 119.18469 & $-0.005083^{* *}$ & 136.3 & 55.6 & & 70.2 \\
\hline \multirow[t]{4}{*}{$\mathrm{Mg}$} & Inga & 118.89176 & $0.000512^{\mathrm{ns}}$ & --- & --- & --- & 3.3 \\
\hline & Bananeira & 131.63323 & $0.001222^{\mathrm{ns}}$ & --- & --- & --- & 20.7 \\
\hline & Gliricidia & 117.93262 & $-0.005600^{*}$ & 123.8 & 50.9 & & 63.2 \\
\hline & Peach palm & 109.89944 & $-0.005757 * *$ & 120.3 & 46.3 & & 74.5 \\
\hline
\end{tabular}

${ }^{*}$ and ${ }^{* *}$ : Significant, respectively, at $5 \%$ and $1 \%$.

DM-GLI, from August pruning, presented $\mathrm{t} 1 / 2$ between 60.5 days of $\mathrm{K}$ and 74.3 days of $\mathrm{P}$ ( 01 to 15 October) during flowering and pinhead stages, with less demand of nutrients for fruiting.

Therefore, in August pruning, the $\mathrm{t} 1 / 2$ of nutrients from the DM-GLI, between 60.5 days of $\mathrm{K}$ and 74.3 days of $\mathrm{P}$ ( 01 to 15 October), coincided with the flowering and pinhead stages, of lower nutrient demand for fruiting. In March pruning, during ripe stage, DM-GLI presented $\mathrm{t} 1 / 2$ between 46.8 days from $\mathrm{K}$ to 128.5 days from $\mathrm{N}$ (14 May to 04 August), coinciding with stages of low nutrient accumulation in fruits (Partelli et al., 2014) and the dormancy stage after harvest (Marsetti et al., 2013). Therefore, in this period, there is a great availability of nutrients from DM-GLI, with low potential to contribute to coffee nutrition.
With DM-ING, in August pruning (second evaluation), there was a rapid release of $\mathrm{K}$ with $\mathrm{t} 1 / 2$ at 63.6 days (04 October), coinciding with the pinhead stage. The other macronutrients showed a gradual release between 137.8 days of P (17 December) and 263.2 days of Mg (22April), between the beginning of fruit grown at the end of ripening, concerning with higher demand. At the end of ripe stage, in the March pruning (third evaluation), the $t 1 / 2$ of the macronutrients was not reached, indicating immobilization and accumulation on the soil. This is due to the greater recalcitrance of the genus Inga. I. edulis leaf presents 24 weeks of $\mathrm{N}$ half-life (Leblanc et al., 2006) and I. subnuda presents a slow decomposition with $35 \%$ of $\mathrm{N}, 50 \%$ of $\mathrm{P}$ and $82 \%$ of $\mathrm{K}$ released at 150 days, and without adjustments for $\mathrm{Ca}$ and $\mathrm{Mg}$ (Duarte et al., 2013). In the present study, with whole branches, greater recalcitrance was observed. 
The behavior of DM-BAN was similar to DM-ING. In the second evaluation, initiated in August, the t1/2 of the nutrients varied from 62.3 days $(\mathrm{K})$ to 135.2 days $(\mathrm{Ca})$ in the DM-BAN. However, it is not possible to establish a relationship with the phenological stages of coffee, because the harvest is not concentrated on a date. In the evaluation started in March, DM-BAN t1/2 was only reached from $\mathrm{K}$ at 92.3 days, indicating a slow decomposition according to (Brito et al., 2017). Unlike banana residues, in the three evaluations of the DM-PP, the remaining $\mathrm{N}$ at 150 days were $20.6 \%, 23.8 \%$ and $21.5 \%$, indicating fast decomposition, although slower than that observed by Pereira et al. (2015) with $99.4 \%$ of the $\mathrm{N}$ released at 112 days with crushed and buried leaves. This rapid release of nutrients after each harvest, points to a favorable effect of DM-PP.

The fertilization for CMON, CING, CBAN, CGLI and CPP was 279, 279, 281, 274 and $274 \mathrm{~kg} \mathrm{ha}^{-1}$ of $\mathrm{N}$, respectively (Prezotti, 2020). The recommended $\mathrm{K}$ was only for CING and CBAN, 10 and $66 \mathrm{~kg} \mathrm{ha}^{-1}$, and no application of liming and $\mathrm{P}$ in all treatments. The compost provided $98.00 \mathrm{~kg} \mathrm{ha}^{-1}$ of $\mathrm{K}$, being sufficient to meet the recommendations. N-compost supply was $147.12 \mathrm{~kg} \mathrm{ha}^{-1}$ year $^{-1}$, between $52.4 \%$ and $52.7 \%$ of the recommendation. The sum of the $\mathrm{N}$ of the compost plus the $\mathrm{N}$ released from the pruning of Aug/2016 and Mar/2017 (Tables 3, 6 and 7) was $319.27 \mathrm{~kg} \mathrm{ha}^{-1}$ in CGLI(13.6\% above the recommendation) and $245.54 \mathrm{~kg} \mathrm{ha}^{-1}$ in CING $(12.0 \%$ below the recommendation).

Part of the N, added by pruning, comes from biological fixation derived from the atmosphere ( $\% \mathrm{Ndfa})$, and part of the $\mathrm{N}$ of the soil. In I. edulis, Leblanc et al. (2006) observed 57\% of Ndfa and Kurppa, Leblanc and Nygren (2010), 74\% to 81\%. In gliricidia there are observations of $85 \%$ (Kurppa; Leblanc; Nygren, 2010) and 55\% (Apolinário et al., 2016), with Nygren et al. (2012) reporting between $50 \%$ and $92 \%$ of Ndfa in five field experiments with different pruning intervals. Considering $60 \% \mathrm{Ndfa}$ of legumes added to $\mathrm{N}$-compost, the deficit in $\mathrm{N}$ input would be $10.9 \%$ in CGLI and $26.1 \%$ in CING, indicating less than necessary contributions, which may limit coffee productivity.

According to the results, the $\mathrm{N}$ release of the DMING (August pruning) is slow and gradual, reaching all the fruiting stages. The $\mathrm{N}$ released of DM-GLI is, predominantly, in stages of low nutrients demand, at flowering and pinhead stages in August pruning, and at the end of ripeness in March pruning. Possibly, an intermediate pruning of gliricidia, coinciding with the rapid swelling stage, could improve the synchrony with the coffee tree. Another option would be the consortium of gliricidia and inga, considering that the mixture of pruning, with labile and recalcitrant materials is favorable, reducing the capacity of binding of polyphenols to proteins (Handayanto; Cadish; Giller, 1994), which can guarantee greater release of $\mathrm{N}$.

\section{CONCLUSIONS}

Gliricídia and peach palm tend to have higher rates of decomposition and lower inga and banana.

The decomposition rates were lower in experiments started in March and higher in August.

The release of nutrients from the dry matter of glircídia, after the March pruning, occurs in a period of low nutritional demand for coffee and in August, it occurs in a period of low demand for the formation of coffee fruits.

The decomposition of the dry matter of inga starting in August is slow, with release of nutrients in the various stages of fruiting of the coffee tree.

Inga and banana have high residual values of nutrients at 270 days in the decomposition started in March.

\section{ACKNOWLEDGMENTS}

The Fundação de Amparo à Pesquisa do Estado do Espírito Santo (FAPES), Secretaria de Estado de Agricultura, Abastecimento, Aquicultura e Pesca (SEAG) and the Consórcio Brasileiro de Pesquisa e Desenvolvimento do Café (CBP\&DCafé) are acknowledged for research funding. To Dr. Lúcio Herzog De Muner, for implementing the project. The authors thank Conselho Nacional de Desenvolvimento Científico e Tecnológico do Brasil (CNPq) for the fellowship.

\section{REFERENCES}

ACOSTA, J. A. A. et al. Fitomass decomposition and nitrogen release of cover crops in function of the level of residue input to soil under no-tillage system. Ciencia Rural, 44(5):801-809, 2014.

AITA, C.; GIACOMINI, S. J. Decomposição e liberação de nitrogênio de resíduos culturais de plantas de cobertura de solo solteiras e consorciadas. Revista Brasileira de Ciência do Solo, 27(4):601-612, 2003.

ALVARES, C. A. et al. Köppen's climate classification map for Brazil. MeteorologischeZeitschrift, 22(6):711-728, 2013.

APOLINÁRIO, V. X. O. et al. Arboreal legume litter nutrient contribution to a tropical silvopasture. AgronomyJournal, 108(6):2478-2484, 2016.

BONA, F. D. et al. Carbono orgânico no solo em sistemas irrigados por aspersão sob plantio direto e preparo convencional. Revista Brasileira de Ciência do Solo, 30(5):911-920, 2006.

BRITO, C. F. B. et al. Production, decomposition and chemical characteristics of banana litterfall. Revista Caatinga, 30(1):45-52, 2017. 
COSTA, N. A. et al. Recomendações técnicas para o cultivo da banana orgânica. Vitória: Incaper, 2006. 48p. (Documentos, 144).

CRUZ, C. D. GENES - A software package for analysis in experimental statistics and quantitative genetics. Acta Scientiarum. Agronomy, 35(3):271-276, 2013.

DAMATTA, F. M. et al. Ecophysiology of coffee growth and production. Brazilian Journal Plant Physiolgy, 19(4):485-510, 2007.

DUARTE, E. M. G. et al. Decomposition and nutrient release in leaves of atlantic rainforest tree species used in agroforestry systems. Agroforest Systems, 87:835-847, 2013.

FARFÁN, V. F.; BAUTE, B. J. E. Efecto del sombrío con especies leguminosas a diferentes densidades de siembra sobre la producción de café. Cenicafé, 61(1):035-045, 2010.

FERRÃO, R. G. et al. Cultivares de café conilon. In: FERRÃO, R. G. et al. Café conilon. Vitória, ES: Incaper, $2^{\mathrm{a}}$ edição. 2017. 702p.

GIACOMINI, S. J. et al. Carbon and nitrogen mineralization in soil combining sewage sludge and straw. Revista Brasileira de Ciência do Solo, 39(5):1428-1435, 2015.

GRAÇA, M. A. S.; BARLOCHER, F.; GESSNER, M. O. Methods to study litter decomposition - A practical guide. Springer, Netherlands. 2005. 329p.

HANDAYANTO, E.; CADISCH, G.; GILLER, K. E. Nitrogen release from prunings of legume hedgerow trees in relation to quality of the prunings and incubation. Plant and Soil, 160:237-248, 1994.

ISAAC, M. E.; BORDEN, K. A. Nutrient acquisition strategies in agroforestry systems. Plant Soil, 444:1-19 2019.

KABA, J. S. et al. Atmospheric nitrogen fixation by gliricidia trees (Gliricidia sepium (Jacq.) Kunth ex Walp.) intercropped with cocoa (Theobroma cacao L.). PlantSoil, 435:323-336, 2019.

KREPSKY, P. B. et al. Chemical composition and vasodilatation induced by Cuphea carthagenensis preparations. Phytomedicine, 19(11):953-957, 2012.

KURPPA, M.; LEBLANC, H. A.; NYGREN, P. Detection of nitrogen transfer from N2-fixing shade trees to cacao saplings in 15N labelled soil: Ecological and experimental considerations. Agroforestry Systems, 80:223-239, 2010.

LEBLANC, H. A.; NYGREN, P.; MCGRAW, R. L. Green mulch decomposition and nitrogen release from leaves of two Inga spp. in an organic alley-cropping practice in the humid tropics. Soil Biology \& Biochemistry, 38(2):349358, 2006.

MARSETTI, M. M. S. et al. Déficit hídrico e fatores climáticos na uniformidade da florada do cafeeiro conilon irrigado. Revista Brasileira de Agricultura Irrigada, 7(6):371-380, 2013.

MUCHECHETI, F.; MADAKADZE, I. C. Yield and nitrogen recovery of rape (Brassica napus 1.) in response to application of leguminous leaf litter and supplemental inorganic nitrogen. Experimental Agriculture, 52(4):518-536, 2016.

MUNROE, J. W.; ISAAC, M. E. N2-fixing trees and the transfer of fixed-N for sustainable agroforestry: A review. Agronomy for Sustainable Development, 34:417-427, 2014.

NYAMAI, D. O. Investigations on decomposition of foliage of woody species using a perfusion method. Plant and Soil, 139:239-245, 1992.

NYGREN, P. et al. Symbiotic dinitrogen fixation by trees: An underestimated resource in agroforestry systems? Nutrient Cycling Agroecosystem, 94:123160, 2012.

PARTELLI, F. L. et al. Dry matter and macronutrient accumulation in fruits of Conilon coffee with different ripening cycles. Revista Brasileira de Ciência do Solo, 38(1):214-222, 2014.

PAUL, E. A.; CLARK, F. E. Dynamics of residue decomposition and soil organic matterturnover. In: PAUL, E. A. Soil microbiology and biochemistry. $2^{\mathrm{a}}$ ed. San Diego: Academic press. p.158-179, 1996.

PAULA, P. D. et al. Decomposição das podas das leguminosas arbóreas Gliricidia sepium e Acacia angustissima em um sistema agroflorestal. Ciência Florestal, 25(3):791-800,2015.

PEREIRA, M. S. et al. Mineralização do resíduo da pupunheira em condições de campo e laboratório. Engenharia Agrícola, 35(5):918-930. 2015.

PÉREZ-MARIN, A. M.; DE ARRUDA SARMENTO, M. I.; VENDRUSCOLO, J. Decomposição de esterco bovino e de biomassa de Gliricídia sepium em Neossolo Regolítico. Revista Verde de Agroecologia e Desenvolvimento Sustentável, 13(4):419-426, 2018.

PETIT-ALDANA, J. Litter decomposition process in coffee agroforestry systems. Journal of Forest and Environmental Science, 35(2):121-139, 2019. 
PREZOTTI, L. C. Sistema de recomendação de calagem e adubação. 2020. Available in: $<$ https://incaper.es.gov. br/>. Access: July, 01, 2020.

RIBAS, R. G. T. et al. Decomposição, liberação e volatilização de nitrogênio em resíduos culturais de mucuna-cinza (Mucuna cinerea). Ciência e agrotecnologia, 34(4):878-885, 2010.

SILVA, G. T. A. et al. Chemical composition and decomposition rate of plants used as green manure. Scientia Agricola, 65(3):298-305, 2008.

SOUZA, G. B. et al. Método alternativo para determinação de fibra em detergente neutro e detergente ácido. São Carlos: EMBRAPA
Pecuária Sudeste, 1999. 21p. (Boletim de pesquisa n. 4).

WIEDER, R. K.; LANG, G. E. A critique of the analytical methods used in examining decomposition data obtained from litter bags. Ecology, 63(6):1636-1642, 1982.

ZAPATA ARANGO, P. C. Composition and structure of shade canopy in coffee agroforestry systems of three municipalities of Cundinamarca, Colombia. Ciência Florestal, 29(2):685-697, 2019.

ZAHARAH, A. R.; BAH, A. R. Patterns of decomposition and nutrient release by fresh Gliricidia (Gliricidiasepium) leaves in an ultisol. Nutrient Cycling in Agroecosystems, 55:269-277, 1999. 